\title{
SUSTAINABLE DEVELOPMENT: THE ROLE OF PRECAUTIONARY PRINCIPLE IN ADVANCING ISLAMIC BANKING IN AFRICA
}

\author{
Hakeem Ijaiya \\ Associate Professor \\ University of Ilorin, Nigeria. \\ hakeemijaiya@gmail.com
}

\begin{abstract}
Principle 16 of the Rio Declaration on Sustainable Development defined Precautionary Principle as the taking of preventive measures without having to wait until the reality and seriousness of the threat become fully known. The study examines the measures adopted by Islamic Banks in Nigeria to create essential mechanisms to achieve sustainable development. The study identifies the relationship between Islamic banking and sustainable development. The qualitative approach is used. The qualitative approach includes content, deductive, and inductive analysis as well as comparative method. The references used in this study are the primary and secondary book. Both materials are analysed accordingly to get the information related to this study. The study found that the precautionary principle plays an important role in the area of environmental law and Islamic banking in Nigeria. The study recommends the adoption of the precautionary principles in promoting Islamic banking system in Nigeria.
\end{abstract}

Keywords: environmental law, sustainable development, precautionary principle, Islamic banking 


\section{INTRODUCTION}

Sustainable development ${ }^{1}$ involves all measures towards the protection of the environment. Thus for commercial activities such as banking to thrive in a society, a sustainable environment must be put in place (Ogbodo, S.G., 2010). Banking institution is very important to a nation. Bank ${ }^{2}$ plays an essential role to the development of a country. Banks serves many products which include saving and investment in order to increase capital, subsequently generate wealth. Even thought, bank is very essential to the nation; however to what extent, bank especially Islamic banking accept the precautionary principle ${ }^{3}$ in Nigeria is the focus of the study.

\section{PRECAUTIONARY PRINCIPLE}

The Oxford Concise Dictionary defines Precaution as "An action taken before hand to avoid risk or to ensure a good result". Precaution also referred to as "precautionary principle", "the precautionary approach" and the "principle

$1 \quad$ The Brundtland Report of the United Nations Commission on Environment and Development defines the concept of sustainable development as development that meets the needs of the present without compromising the ability of future generations to meet their own needs. The objectives of sustainable development include social progress and equity, environmental protection, conservation of natural resources and stable economic growth. Sustainable development rests on three pillars, economic activities, social equality and environmental activities that promote the ability of the present and future generations. The key principles of sustainability are; the principle of intergeneration, the precautionary principle, the principle of intergenerational and intergenerational equity and the polluter pays principles.

2 Basically, the banking system can be divided into two. The first system is known as Conventional banking. The second system is known as Islamic banking or also known as Shariah banking. Islamic banking system is based on the teachings of Islam, the al-Qur' an and Hadith.

3 The precautionary principle approach may be considered as one of the sources of the international environmental law, as a general principle of law and also an international customary law in order to attain sustainable development. 
of precautionary approach" is essential to protect the environment including human health (Preston, C.J., 2006: 18-20). ${ }^{4}$

The most widely accepted definition of precautionary principle is contained in principle 15 of the Rio Declaration thus;

"In order to protect the environment, the precautionary approach shall be widely applied by States according to their capabilities. Where there are threats of serious or irreversible damage, lack of full scientific certainty shall not be used as a reason for postponing cost-effective measures to prevent environmental degradation. ${ }_{5}$

Also the 1998 Wingspread Conference on the Precautionary Principle defined precautionary principle as;

"When an activity raises threats to harm to human health or the environment, precautionary measures should be taken even if some causes and effect relationships are not fully established scientifically."

The advocates for precautionary action against speculated threats have traditionally referred to commonsense notions such as "better to safe than sorry" and "better to err on the side of caution". The precautionary principle has been applied to biotechnology, chemical pollutants, radiation exposure, food safety, medical technology, occupational hazards, exposure to pathogenic organisms, and other public health concerns such as banking.

The precautionary principle is to guide Administrators and Regulators who are required to make decisions or develop policy in circumstances where

$4 \quad$ The precautionary principle permits the taking of preventive measures without having to wait until the reality and seriousness of the threat become fully known. The precautionary principle embraces the concept of proportionality. In applying the precautionary principle, measures should be adopted that are proportionate to the threat. There must be proportionality of response or cost effectiveness of margins of error to show that the selected precautionary measure is not unduly costly.

5 The Earth Summit at Rio Janeiro, 1992. Since the Rio Declaration a number of the environmental treaties have adopted the precautionary principle, e.g. Article (3) (f) of the Bamako Convention,1991 states that "The preventive approach to pollution which entails, inter alia, preventing the release into the environment of substances which may cause harm to humans or the environment without waiting for scientific proof regarding such harm. These parties shall co-operate with each other in taking the appropriate measures to implement the precautionary principle to pollution prevention through the application of clean production method." 
scientific information is imperfect and the likely impact of their actions is uncertain.

The purpose of precautionary principle is to enable decision makers to consider the likely effects of their harmful effects of their activities on their environment before they pursue those activities.

\section{PRECAUTIONARY PRINCIPLE IN ISLAM}

Precautionary principle under Islamic law is derived from Sadd aldhari' $a h^{6}$ which means preventing an evil before it actually materializes ${ }^{7}$. The precautionary principle in Islam is a measure towards blocking the means to harmful result. Precautionary principle, which has its basis in The Qur'an, is intended to forestall deeds or policies that might lead to impermissible conduct, or may have harmful effect on the people, environment and the biodiversity.

The legality of sadd al-dhari'ah is established in Qur'an 2: 104. ${ }^{8}$ Also in the Sunnah where Prophet forbede the creditor from receiving gift from the debtor ${ }^{9}$. Islamic law primarily seeks to maximize every benefit for mankind and prevent any possible harm that will bring about total destruction of the entire mankind.

${ }_{6} \quad$ The concept of sadd al-dhari ' $a$ h is founded in the idea of preventing an evil before it actually materializes.

7 A precautionary concept, which is regarded as one of the secondary sources of Islamic law is sadd al-dhari 'ah (blocking the lawful means to an unlawful of harmful end).

8 Qur'an 2: 104 reads "O believers! Address not the Prophet by the word ra'ina, but address him respectively and listen to him". The word ra'ina in the verse is deliberately left without a translation because it is a homonym. The two meanings of the word are different; the first may mean "please look at us" but with a slight twist, the same word means "our shepherded". The Jews used to insult the Prophet (SAW) with the same word. So, in order to block the means to such word, which has the potentiality of being used in the abusive sense, Allah ordered the believers to use a different term.

9 There are a number of prophetic dispositions that were specifically meant to block the lawful means to a harmful or unfavorable end. An example of such is the ruling of the Prophet (SAW) where he forbade the creditor from receiving gift from the debtor, least such gift may be received as an alternative to survey. 


\section{ISLAMIC BANKING IN AFRICA}

Islamic banking also known as participant banking, ${ }^{10}$ is banking activity that is consistent with the principles of Islamic law and its practical application through the development of Islamic economics. The system prohibits the fixed or floating payment or acceptance of specific interest or fees like usury for loans of money. ${ }^{11}$

10 Islamic banking is based on the banking activities according to Shariah law called fiqh transactions, regulation of the transaction. Rules and practices derived from the al-Quran and Sunnah and other secondary sources of Islamic as agreed in the collective opinion among scholars Shariah (ijma'), analogy (qiyas) and personal reasoning (ijtihad). Application of Islamic banking can be seen in the practical through the development of Islamic economics. Islamic banking is free of riba. This is because Shariah prohibits the payment or receipt of interest from loans and investing in businesses that provide goods or services is considered contrary to the principles. At the end of the $20^{\text {th }}$ century, Islamic banks become famous bank on the growing awareness and to maintain harmonious Islamic community itself. Today, Islamic banking is not only applicable to the muslim community but also non-muslim communities, mostly refer to as Islamic banking services.

11 Islamic banking is a banking based on Islamic law (Shariah). It follows the Shariah rules known as fiqh muamalat (Islamic rules on transactions). In other words, it is a Shariah-compliant banking. The rules and practices of fiqh muamalat came from the Quran and the Sunnah, and other secondary sources of Islamic law such as opinions collectively agreed among Shariah scholars (ijma'), analogy (qiyas) and personal reasoning (ijtihad). The most important difference between Islamic and conventional banking is that Islamic banking is ethical in accordance with the Shariah Islamic banking, while pursuing business objectives, aims at ensuring social justice and human welfare through forbidding all forms of economic activities which are morally or socially injurious, ensuring ownership of wealth legitimately acquired, allowing an individual to retain any surplus wealth and seeking to prevent the accumulation of wealth in a few hands to the detriment of society as a whole. It uses all the known financial institutions and commercial modes of transaction in Islamic jurisprudence in offering its services and products to its customers. One of such banking Islamic banking technique is the musharakah which is principally of profit and loss sharing. Islamic finance has tremendous potential to at least partly support the funding gaps in Africa while enhancing the financial inclusion rates in the region. According to reports, The Islamic banking segment in Africa has plentiful opportunities supported by Africa's large and under-served Muslim population and increasing awareness of Shari'a-compliant products. In addition, it provides government institutions an alternative financing mechanism to support the country's capital expenditure needs. The methods undertaken, united with the natural advantages offered by Africa, are likely to lead to stronger growth of the Islamic finance industry in the region. However, Islamic 
Islamic Bank in Africa is a business entity which collects funds from the public in savings and share to the public in loans or other forms in order to improve the standard of living of the people.

Just like other financial institutions, the basic mechanism of Islamic bank is to receive funds from customers and channel the money to other customers in need. ${ }^{12}$

\section{ROLE OF THE PRECAUTIONARY PRINCIPLE AND ISLAMIC BANKING TOWARDS ACHIEVING SUSTAINABLE DEVELOPMENT IN NIGERIA}

Paragraph 7 of the Bergen Ministerial Declaration on Sustainable Development, 1990 states that;

"Where there are treats of serious or irreversible damage, lack of full scientific certainty should not be used as a reason for postponing measures to prevent environmental degradation." 13

The provision of paragraph 7 tries to emphasize the adoption of precautionary principle by using the words of "should not be".

Also Principle 15 of the Rio declaration provides thus;

finance industry is still in its infancy on the continent. Of the total $600+$ Islamic financial institutions worldwide, only about 40-50 are operating on the African continent, which is home to a massive Muslim demographic that represents over $50 \%$ of the total population. Recent reports indicate that over $65 \%$ of the total populations on the continent are unbanked and that banking penetration stands at $60 \%$ in urban areas and less that $20 \%$ in the rural areas. This indicates a promising future for Islamic finance in Africa. However to capture this tremendous potential, the regional industry must overcome certain challenges which include a lack of Shari'ah-compliant investment vehicles, fragile legal and regulatory frameworks and, importantly, the lack of awareness by many end-users and consumers.

12 Like any conventional bank, an Islamic bank is a financial intermediary and trustee or creditor of people's money with the difference that the Islamic banks reject the receipt and payment of riba (interest) on any of its operations. What distinguish an Islamic bank from a conventional one is that the Islamic bank keeps in view certain social objectives intended for the benefit of society. The Islamic banks aim to establish distributive justice free from all sorts of exploitation. From the Islamic point of view, business transactions can never be dissociated from the moral objectives of the society.

13 The Bergen Ministerial Declaration on Sustainable Development in Economic Commission for Europe (ECE) Region was the first instrument to link with sustainable development principle and the precautionary principle. 


\section{"Where there are threats of serious or irreversible damage, lack of full scientific certainty shall not be used as reason for postponing cost-effective measures to prevent environmental degradation."}

The provision of the Rio Declaration has highlighted that the application of the precautionary principle as mandatory based on the words of "shall not be".

The current approach, that is, the precautionary principle approach required the project proponent who intends to develop a project to bring evidences that the project will not cause harm to the environment in order to attain sustainable development. Whereas, the traditional approaches indicate that the burden of proof is on the shoulder of the party who oppose a development project. Later the oppose party to the said development project is required to bring evidences to proof that the said development project is likely to cause harm to the environment.

Environmental Impact Assessment ("EIA") has been one of the most effective and practical tools to support the implementation of sustainable development in Nigeria. ${ }^{14}$ Environmental Impact Assessment (EIA) is a process of evaluating the likely environmental impacts of a proposed project or development, taking into account inter-related socio-economic, cultural and human-health impacts, both beneficial and adverse. The United Nations Environmental Programme (UNEP) defines EIA as a tool used to identify the environmental, social and economic impacts of a project prior to decisionmaking. EIA is an important instrument to balance environmental protection and economic growth ${ }^{15}$. It is a systematic process of identifying, predicting and evaluating potential impacts associated with a developmental project. ${ }^{16}$

14 Environmental Impact Assessment is defined as a process or set of activities designed to contribute pertinent environmental information to project or programme decision making... a process which attempts to identify, predict and assess the likely consequences of proposed development activities... a planning aid concerned with identifying, predicting and assessing impacts arising from proposed activities such as policies, programmes, plans and development projects which may affect the environment... a basic tool for the sound assessment of development proposals to determine the potential environmental, social and health effects of a proposed development. EIA means an assessment of the possible positive or negative impact that a proposed project may have on the environment, together consisting of the natural, social and economic aspects.

15 Basically, EIA came in as a result of the need to balance social, economic and environmental challenges, which simply put, are to ensure sustainable development.

16 EIA process potential problems that would be associated to developments are dealt with even before the development itself commences. 
The principal law on EIA in Nigeria is the Environmental Impact Assessment Act, $1992 .{ }^{17}$ The Act makes EIA mandatory for development projects likely to have adverse impacts on the environment prior to implementation. ${ }^{18}$ The EIA Act made it compulsory for certain projects to have an EIA before they can be carried out. These projects are classified into three categories, namely; Projects that require full and mandatory EIA. ${ }^{19}$ Projects where full EIA's are not so mandatory except if it is within environmentally sensitive area ${ }^{20}$, and Projects that are beneficial to the environment. ${ }^{21}$ EIA process in Nigeria passes through;

17 Laws of the Federal Republic of Nigeria. 2000. Before 1992 there are Country Planning Decree, 1992 and the Petroleum Act, 1969.

18 Before the enactment of EIA Act in Nigeria, project appraisals were limited predominantly to feasibility studies and economic-cost-benefit analysis. Most of these appraisals did not take environmental costs, public opinion and social and environmental impacts of development projects into consideration. S. Nwoko, (2013) Evaluation of Environmental Impact Assessment System in Nigeria.

19 These include Agriculture/ Agro Allied, Fisheries, Industry (Manufacturing), Food, Beverages and Tobacco, Infrastructure, Housing, Airports, Ports, Drainage and Irrigation, Power Generation, Petroleum, Mining, Quarries, Waste Treatment Disposals, Water Supply, Land Reclamation and Breweries.

20 (Coral reefs, mangrove swamps, small islands, tropical rain forest with erosion). These include Agriculture and Rural Development (Aforestation/ Reforestation project, small scale irrigation or drainage, small scale agriculture, saw milling/wood logging, Rubber processing and fish processing), Mini Hydro Power Development (e.g. textile chemical industry, small scale power transmission) Renewable Energy Development etc.

21 These include institutional development, health programmes, family planning programmes nutritional programmes, educational programmes and environmental awareness. 
Consideration of Alternatives, ${ }^{22}$ Screening, ${ }^{23}$ Scoping, ${ }^{24}$ Baseline Study, ${ }^{25}$ Assessing impacts, ${ }^{26}$ Mitigation $^{27}$, Public consultation with stakeholders, ${ }^{28}$

22 EIA should provide an environmental input on the decisions on what is to be constructed and where it is to be located. This provides the best opportunity to avoid significant environmental effects by steering clear of environmentally sensitive locations and selection designs and processes that have a reduced environmental impact.

23 This refers to the decision as to whether an EIA is required or not or the environmental effect a particular project would have.

24 The purpose of scoping is to identify projects that are likely to have significant effects. The identification of key effects is usually undertaken using a combination of professional judgment and gathering of other people's opinions, particularly the determining authority and government agencies. This is where public participation in the EIA process commences.

25 Where there is strong evidence that a proposed development will impact on the environment negatively, a baseline study is required. This study will establish the inventory of the site itself and can include ecological survey for biodiversity, pollution impacts e.g. ground noise disturbance, archeological surveys to ascertain special sites of cultural heritage, etc.

26 Here the environmental effects of a developmental proposal are predicted. A detail EIA Report is prepared. Three elements are involved. The first element is to understand the baseline conditions. The second element is to predict the magnitude of the impacts. The third element is to assess the significant of the impacts.

27 When the significant effects are identified, the developer and the consultants may then decide to bring about elimination or prediction of the impacts in order for the development to be approved.

28 Consultation with stakeholders is essential during the EIA process. Public consultation documents seek to communicate the anticipated impacts and proposed mitigations of the project's impact and disclosure report should describe the environmental, socioeconomic and community health effects of the project. 
Review and Decision making, ${ }^{29}$ Final Decision-Making/ Authorization, ${ }^{30}$ PostProject Authorization Activities ${ }^{31}$ and Commissioning Audit. ${ }^{32}$

EIA is also widely accepted as a mechanism for public participation in planning processes and decision-making and as a tool to provide information and data to the public regarding projects and other activities.

Islamic Banking is mostly affected for failure to comply with EIA process. For instance, The Standard Chartered Bank in Lagos, Nigeria was erected without complying with Section 4(b) of the Nigeria EIA Decree 86 of May 1992. Dr. Tunji Braithwaite sometime in December, 2014 instituted an action against the Bank at the Ikeja High Court to stop the construction of

29 See Sections 25 and 37 EIA Act. The findings of the EIA are written up in an environmental statement and submitted to the review panel together with the application for consent for approval. The EIA review panel crosschecks the document for adequate information and evaluates it. The information is evaluated for its relevance to the decision to be made, reliability in terms of information provided and the interpretation of data are sufficient to form a sound basis for a decision. The verification exercise by the independent review body ensures that the information in the EIA report is complete, correct and unbiased.

30 The outcomes of the final decision- making can either be that the project or one of its alternatives is approved, a request for further study/modify for future consideration or that the project is cancelled or rejected altogether. If it is approved, an Environmental Impact Statement and Certificate is issued.

31 See Section 41 EIAAct. The regulatory body is required to carry out its statutory role of ensuring that the project as approved is implemented and monitoring the followup programme for mitigations at the construction, operational and post- closure stages of the project.

32 After the commencement/commissioning of the project, an environmental audit is required to be carried out from time to time. An audit is the process of reviewing activities and records against defined standards or procedures to establish what is being done and how far the process is complying with requirements. 
a 14 story building in Victoria Island, Lagos, Nigeria ${ }^{33}$ for creating negative environmental impact on the environment. ${ }^{34}$

33 Dr Tunji Braithwaite, on Tuesday, 2014 claimed that a 14-storey building being constructed by the Standard Chartered Bank in Victoria Island, Lagos, violated Nigeria's environmental laws. Dr.Tuji Braithwaite had asked the court to stop the project, which is being erected opposite his residence, due to its environmental impact. He also asked the court to grant him N10 billion as damages and an order for the 14-storey building and the multi-level car park to be demolished. Dr. Adejumo, an associate professor in the Department of Urban and Regional Planning of the University of Lagos, in his testimony for the plaintiff said an Environmental Impact Assessment (EAI) was not carried out on the building. According to him, the car park in the building which will accommodate about 120 cars on a daily basis, will lead to noise and air pollution, as well as vehicular traffic in the area. Using a visual aid, the witness said the carbon monoxide from the cars and the three power generating plants sited in the building would lead to emission of gases hazardous to human health. He said: "A simulation of what the building would look like when completed showed that it would have negative environmental impact on its immediate surroundings, including Braithwaite's residence. According to the witness "The EIA did not follow the Federal Government of Nigeria's EIA procedure, especially Section 4(b) of the Nigeria EIA Decree 86 of May 1992," He said the construction of the project did not follow best EIA practices as residents and other stakeholders were not consulted by the bank. However, Counsel to the bank, Mr Adeniyi Adegbomire, described the suit as a "nuisance case" which ought not to be entertained by the court. Adegbomire argued that the plaintiff claims must be particularized, adding that the project had no negative impact on the area, as being alleged. The case has not been concluded.

34 However, the challenge has been that of enforceability of the provision of EIA in Nigeria. In Douglas V. Shell Petroleum Development Company Limited and Others Unreported Suit No. FHC/CS/573/931 where the plaintiff who sought a declaration against the commissioning of a gas project by the defendants without complying with EIA Act was held not to have the locus standi to institute the action. This suggests to mean that governments, corporations and individuals can ignore the provisions of the Act and go ahead to carry out projects without first considering the impact such projects will have on the environment. Despite this problem of enforceability. There is still a good left in the Act. In Sanni Abacha V. Gani Fawehinmi (2002) FWLR (PT.4) 533 the supreme court held that enforceability is still possible to a great extent. The court said that instead of relying on the provisions of the Constitution on enforcement of fundamental human rights (which inferably include right to sustainable environment) an aggrieved party can come under the provisions of Article 24 of the African Charter on Human and People's. 
In Nigeria, the Environmental Impact Assessment Act, 1992 has adopted the precautionary principle approach, especially based on section 2(4). The provision of Section 2(4) of the Act requires the project proponent to bring evidences in the form of a report which indicate that the development project will not cause harm to the environment in order to achieve sustainable development and if the project is likely to harm the environment, the project proponent is required to proposed measures that shall be undertaken to prevent, reduce or control the adverse impact on the environment. ${ }^{35}$

\section{CONCLUSION}

Islamic banking in Nigeria has incorporated the precautionary principle. The precautionary principle plays an important role in the area of environmental law and governance. The application of precautionary principle has enhanced the growth of Islamic banking in Nigeria. The Environmental Impact Assessment Act, 1992 has been the major inspiration in promoting Islamic banking.

\section{REFERENCES}

Alaro, A. A. (2010). "Islamic Law of Banking: A Discourse of Riba and Its Modern Instruments," Journal of Islamic Law and Judiciary, vol. 5.

Alaro, A. A. (2010). "Wasail al-Ihtiyat li Man Yuhakam Ghiyabiyyan fi al-Fiqh al-Islami," Al-Asaalah Journal, vol. 1, no. 2.

35 Section 4 of the Act stipulates minimum content of environmental impact assessment as follows (a) A description of the proposed activity (b) A description of the potential affected environment, including specific information necessary for identifying and assess the environmental effect of the proposed activity (c) A description of practical activities as appropriate (d) An assessment of the likely or potential environmental impacts of the proposed activity and alternatives, including the direct or indirect cumulative, short-term and long-term effects (e) An identification and description of measures available to mitigate adverse environmental impacts of the proposed activity and an assessment of those measures (f) An indication of gaps in knowledge and uncertainty which may be encountered in computing the required information $(\mathrm{g})$ An indication of whether the environment of any other State or local government area or area outside Nigeria is likely to be affected by the proposed activities or its alternatives (f) a brief non-technical summary of information provided. 
Alaro, A.A. (2009). "Legal and Operational Frameworks of Islamic Windows in Conventional Financial Institutions: Nigeria as a case study," Paper presented at the 1st University of Ilorin International Conference on Islamic Banking and Finance, jointly organized by Department of Islamic Law, UNILORIN and Islamic Research and Training Institute, Jeddah, Saudi-Arabia, October 6-8, 2009.

Cranson, R. (1997). Principles of Banking Law. New York: Oxford University Press.

Ijaiya, H. (2013). The Principle of Sustainable Development: An Appraisal of the Polluter Pays Principles in the Nigeria Oil and Gas Industry. Malaysia: Legal Network Series.

Malcom, R.A. (1994). Guide Book to Environmental Law. Sweet and Maxwell. Milnes, H.J. (1996). The Law and Practice of Banking. Pitman Publishers.

Ogbodo, S.G. (2010). "The Paradox of the Concept of Sustainable Development under Nigeria's Environmental Law," Journal of Sustainable Development, vol. 3, no. 3.

Preston, C.J. (2006). "Ecological Sustainable Development in Australia and Asia," Paper presented at Environmental Law Seminar on 28th August, 2006 in Wellington, N.Z. 
Journal of Shariah Law Research (JSLR) 